\title{
Bcl-2-Associated Transcription Factor 1
}

National Cancer Institute

\section{Source}

National Cancer Institute. BCl-2-Associated Transcription Factor 1. NCI Thesaurus. Code C115996.

Bcl-2-associated transcription factor 1 (920 aa, 106 kDa) is encoded by the human BCLAF1 gene. This protein is involved in the positive regulation of apoptosis and the negative regulation of gene transcription. 